\title{
Effects of guar gum and cellulose on glucose absorption, hormonal release and hepatic metabolism in the pig
}

\author{
BY C. SIMÕES NUNES* \\ Département NASA, INRA-CRJ, 78350 Jouy-en-Josas, France \\ AND K. MALMLÖF† \\ Department of Animal Nutrition and Management, Swedish University of Agricultural Sciences, \\ S-75007 Uppsala, Sweden
}

(Received 17 July 199I-Accepted 12 November 199I)

\begin{abstract}
Six Large White pigs (mean body-weight 59 (SE 1.7) kg) were surgically fitted with permanent catheters in the portal vein, the brachiocephalic artery and the right hepatic vein, as well as with electromagnetic flow probes around the portal vein and the hepatic artery, and allowed to recover. The non-anaesthetized animals were given a basal non-fibre diet (diet $A$ ) alone or together with $60 \mathrm{~g}$ guar gum $/ \mathrm{kg}(\operatorname{diet} B)$ or $150 \mathrm{~g}$ purified cellulose $/ \mathrm{kg}$ (diet $\mathrm{C}$ ) by substitution for mica. The diets were given for weekly periods and according to a replicated $3 \times 3$ Latin square design. On the last day of each such adaptation period, test meals of $800 \mathrm{~g}$ were given before blood sampling. Sampling was continued for $8 \mathrm{~h}$. Guar gum strongly reduced glucose apparent absorption without changing the absorption and the hepatic uptake profiles. Production rates of insulin, gastric inhibitory polypeptide and insulin-like growth factor-1 (IGF-1) were lowest after guar gum ingestion. However, the reductions in peripheral blood insulin levels caused by guar gum were not associated with a change in hepatic insulin extraction. IGF-1 appeared to be strongly secreted by the gut, whereas the liver had a net uptake of the peptide. Ingestion of guar gum increased the hepatic extraction coefficient of gut-produced IGF-1. Guar gum ingestion appeared also to decrease glucagon secretion.

Cellulose at the level consumed had very few effects on the variables considered.

It is suggested that the modulation of intestinal mechanisms by guar gum was sufficient to mediate the metabolic effects described.
\end{abstract}

Guar gum: Glucose: Liver: Insulin: IGF-1: Pig

Dietary fibre influences events at all levels of the alimentary tract. There is considerable interest in the nutritional and physiological effects of dietary fibre (Laplace \& Lebas, 1981; Heaton, 1983; Johnson, 1990). The possible mechanisms by which dietary fibre acts and improves some disease states such as diabetes, hyperlipidaemia and hyperuraemia are increasingly the subject of experimental work (Hagander et al. 1984; Gulliford et al. 1988; Rémésy \& Demigné, 1989).

Better knowledge is needed of the effects of dietary fibre on the absorption and metabolism of different nutrients. In previous experiments the effects of wheat-straw meal and guar gum on porto-arterial differences of amino-nitrogen, urea, glucose and insulin in pigs have been studied (Malmlöf et al. 1988, 1989). The aim of the present work was to study the quantitative apparent absorption and hepatic metabolism of glucose as well as the production of insulin, glucagon, gastric inhibitory polypeptide (GIP) and insulin-like

* Present address: Société Chimique Roche, B.P. 170, 68305 Saint-Louis Cédex, France.

† Present address: Kabi Pharmacia, Experimental Biology, S-112 87 Stockholm, Sweden. 
Table 1. Composition of experimental diets $(\mathrm{g} / \mathrm{kg})$

\begin{tabular}{lrrr}
\hline Diet ... & A & B & C \\
\hline Hydrochloric casein (UCCP) & 173 & 173 & 173 \\
Peanut oil & 40 & 40 & 40 \\
Maize starch & 601 & 601 & 601 \\
Guar gum & - & 60 & - \\
Purified cellulose & - & - & 150 \\
Mica powder & 150 & 90 & - \\
Mineral mixture* & 25 & 25 & 25 \\
Vitamin mixture & 10 & 10 & 10 \\
Antioxidant & 1 & 1 & 1 \\
\hline
\end{tabular}

* Supplied (/kg diet): dicalcium phosphate $10 \mathrm{~g}$, sea salt $3 \mathrm{~g}$, potassium chloride $4 \mathrm{~g}$, magnesium carbonate $2 \mathrm{~g}$, iron sulphate $600 \mathrm{mg}$, manganese sulphate $160 \mathrm{mg}$, copper sulphate $40 \mathrm{mg}$, zinc sulphate $440 \mathrm{mg}$, potassium iodide $450 \mu \mathrm{g}$, sodium selenite $500 \mu \mathrm{g}$.

$\uparrow$ Supplied (mg/kg diet): vitamin A 1.72 , vitamin $D_{3} 25 \mu \mathrm{g}$, tocopherol acetate 22 , menadione 44 , thiamin hydrochloride $3 \cdot 3$, riboflavin 6 , niacin 36 , calcium pantothenate 30 , pyridoxine hydrochloride 3 , folic acid 2 , inositol $200, p$-aminobenzoic acid 20 , biotin $300 \mu \mathrm{g}$, vitamin $\mathrm{B}_{12} 30 \mu \mathrm{g}$, choline concentrate $6 \mathrm{~g}$.

growth factor-1 (IGF-1) in the growing pig after the ingestion of diets containing purified cellulose or guar gum.

The most reliable information for studying metabolism in the splanchnic bed is obtained by in vivo measurements. This can be done if the rate of blood flow through the liver (arterial and portal supplies) is recorded continuously, and metabolite concentrations are measured via blood samples taken from an artery, one of the hepatic veins and the portal vein. In the present work we have used such an experimental model (Simões Nunes et al. 1989).

\section{MATERIALS AND METHODS}

Animals and diets

Six castrated male Large White pigs (59 (SE 1.7) kg initial body-weight) were used. Each animal was surgically fitted with three catheters placed respectively in the portal vein, the brachiocephalic artery and the right hepatic vein, and electromagnetic flow probes around the portal vein and around the hepatic artery as described by Simões Nunes et al. (1989). The animals were subsequently given a basal non-fibre diet containing $150 \mathrm{~g}$ mica powder (diet A) alone or together with $60 \mathrm{~g}$ guar gum (diet B) or $150 \mathrm{~g}$ purified cellulose (diet C) by substitution of mica powder. The aim when preparing these diets was to produce diets with the same level of starch and protein and, thus, the inclusion of an inert material such as mica powder was indispensable. Each diet was given for 1 week according to a replicate $3 \times 3$ Latin square design. On the last day of each such adaptation period test meals of $800 \mathrm{~g}$ were given before blood samplings. These samplings were continued for $8 \mathrm{~h}$. The dietary composition is given in Table 1. Throughout the experimental period the animals were kept individually in cages which permitted easy access to the cannulas and the probes. To prevent obstruction of the cannulas by blood clots they were rinsed daily with heparinized sodium chloride $(9 \mathrm{~g} / \mathrm{l})$ solution $(100 \mathrm{IU} / \mathrm{ml})$.

\section{Measurements}

Each test meal started at 09.00 hours after a fasting period of $24 \mathrm{~h}$. On the day of each test meal portal vein and hepatic artery blood flow-rates were recorded continuously. Blood was sampled simultaneously from the hepatic vein, brachiocephalic artery and portal vein 
( $4 \mathrm{ml} /$ route) from zero time until $8 \mathrm{~h}$ after the beginning of the meal, every $10 \mathrm{~min}$ during the first $40 \mathrm{~min}$, at 1 hour, every $30 \mathrm{~min}$ during the 2 nd hour and once every $1 \mathrm{~h}$ afterwards. A $2 \mathrm{ml}$ portion of each blood sample from each cannula was collected in ice-chilled tubes containing $10 \mu \mathrm{l}$ heparin (50 IU) and immediately analysed for glucose (Hill \& Kessler, 1961), L-lactic acid (Minaire et al. 1965) and pyruvic acid (Minaire et al. 1967) concentrations. A further $2 \mathrm{ml}$ of blood was collected in ice-chilled tubes containing $20 \mu \mathrm{l}$ heparin and $1000 \mathrm{KIU}$ Trasylol (apronitin)/ml blood for plasma immunoreactive insulin, glucagon, GIP and IGF-1 measurements. Plasma samples were rapidly prepared after centrifugation $\left(1600 \mathrm{~g}, 4^{\circ}, 15 \mathrm{~min}\right)$ and stored at $-80^{\circ}$ until the assay was performed within 2 months after the experiment. Insulin was measured with a commercial assay system (CEA, France; Sorin Biomedica, Spa, Italy) as well as glucagon (Novopharmaceutic, Copenhagen, Denmark) and IGF-1 (Amersham, Les Ulis). GIP was measured according to Rérat et al. (1985). Blood concentrations of all these hormones and hormonal peptides were calculated taking into account the packed cell volume measurements which were made throughout the $8 \mathrm{~h}$ of observation.

\section{Calculations}

The determination of apparently absorbed quantities or net appearance in the portal vein (AQ), produced intestinal or pancreatic hormone quantities (HQ), splanchnic input (SI), hepatic input (HI), hepatic output (HO), hepatic balance (HB), hepatic extraction coefficient (HEC) and splanchnic balance or non-hepatic tissue balance (SB) were calculated according to the following formulas (Simões Nunes et al. 1989):

$$
\begin{aligned}
& A Q \text { or } H Q=(\mathrm{Pc}-\mathrm{Ac}) \times \mathrm{Pf}, \\
& \mathrm{SI}=\mathrm{Ac} \times(\mathrm{Pf}+\mathrm{Haf}), \\
& \mathrm{HI}=(\mathrm{Pc} \times \mathrm{Pf})+(\mathrm{Ac} \times \mathrm{Haf}), \\
& \mathrm{HO}=\mathrm{Hvc} \times(\mathrm{Pf}+\mathrm{Haf}), \\
& \mathrm{HB}=\mathrm{HI}-\mathrm{HO}, \\
& \mathrm{HEC}=(\mathrm{HI}-\mathrm{HO} / \mathrm{HI}) \times 100, \\
& \mathrm{SB}=(\mathrm{Hvc}-\mathrm{Ac}) \times(\mathrm{Pf}+\mathrm{Haf}),
\end{aligned}
$$

where $\mathrm{Pc}$ is the portal concentration, $\mathrm{Pf}$ is the flow in the portal vein, Ac is the arterial concentration, Haf is the flow in the hepatic artery and Hvc is the hepatic vein concentration.

Statistical analysis (Snedecor \& Cochran, 1967) involved standard error of the mean as well as an analysis of variance followed by a Duncan's multiple-range test. These calculations were performed with the Statistical Analysis System (SAS Institute, Cary, $\mathrm{NC})$.

\section{RESULTS}

Blood flow-rates and hepatic and gut movements of glucose, lactic acid and pyruvic acid The nature of the test meal did not affect the blood flow-rate patterns. However, ingestion of the meal was accompanied by an increase in total hepatic blood flow. This increase appeared to be due to an increase in portal flow. For all the animals and all the experiments the mean total hepatic blood flow rate was 3242 (SE 48) $\mathrm{ml} / \mathrm{min}(55$ (SE 0.8$) \mathrm{ml} / \mathrm{kg}$ per min) and the arterial supply to the liver represented on average $20 \%$ of the total blood received by the organ.

The apparently absorbed quantities of glucose were highest for diet $\mathrm{A}$ and lowest for the guar-gum diet. The pattern of absorption was almost the same for the three diets, with the largest absorption rates from the 2 nd to the 5 th hours after the beginning of the meal (Table 
Table 2. Apparently absorbed quantities (net appearance $(g / 8 h)$ in portal vein; $A Q$ ), hepatic balance $(\mathrm{g} / 8 \mathrm{~h} ; H \mathrm{~B})$ and hepatic extraction coefficients $(H E C)$ of glucose, lactic acid and pyruvic acid in the pig after ingestion of the basal non-fibre diet $(A)$ or diets containing guar gum $(B)$ or cellulose $(C)^{*}$

(Mean values and standard deviations for six determinations)

\begin{tabular}{|c|c|c|c|c|c|c|}
\hline \multirow[t]{2}{*}{ Diet... } & \multicolumn{2}{|c|}{ A } & \multicolumn{2}{|c|}{ B } & \multicolumn{2}{|c|}{$C$} \\
\hline & Mean & $\mathrm{SD}$ & Mean & SD & Mean & SD \\
\hline \multicolumn{7}{|l|}{ Glucose } \\
\hline $\mathrm{AQ}$ & $352^{\mathrm{a}}$ & 40 & $240^{\mathrm{b}}$ & 32 & $336^{\mathrm{a}}$ & 24 \\
\hline $\mathrm{HB}$ & 144 & 40 & 104 & 16 & 104 & 40 \\
\hline HEC & 10 & 3 & 8 & 1 & 7 & 3 \\
\hline \multicolumn{7}{|c|}{ Lactic acid } \\
\hline $\mathrm{AQ}$ & $15 \cdot 1$ & $1 \cdot 44$ & $16 \cdot 2$ & 0.64 & $17 \cdot 3$ & 1.76 \\
\hline $\mathrm{HB}$ & $12 \cdot 3$ & $5 \cdot 12$ & $17 \cdot 0$ & $3 \cdot 84$ & $8 \cdot 2$ & 5.94 \\
\hline $\mathrm{HEC}$ & 7 & 5 & 16 & 4 & 12 & 5 \\
\hline \multicolumn{7}{|c|}{ Pyruvic acid } \\
\hline $\mathrm{AQ}$ & $1 \cdot 76^{\mathrm{a}}$ & $0 \cdot 24$ & $0.96^{\mathrm{b}}$ & 0.24 & $1 \cdot 36^{\mathrm{ab}}$ & 0.32 \\
\hline $\mathrm{HB}$ & $1 \cdot 36$ & $0 \cdot 16$ & $1 \cdot 20$ & 0.32 & $1 \cdot 12$ & 0.64 \\
\hline $\mathrm{HEC}$ & 16 & 2 & 16 & 8 & 14 & 8 \\
\hline
\end{tabular}

${ }^{a, b}$ Mean values in the same row with different superscript letters were significantly different $(P<0 \cdot 05)$.

* For details of composition, see p. 694 and Table 1.

2). The hepatic uptake of glucose was highest after diet A and lowest after diets B and C which were similar. The glucose hepatic uptake pattern followed that of absorption and it represented 41,43 and $31 \%$ of the absorbed quantities respectively for diets A, B and C. The mean hepatic extraction rate was about $8 \%$. Thus, glucose reaching the peripheral circulation represented $59 \%$ of that absorbed from diet A, $57 \%$ for diet B and $69 \%$ for diet $\mathrm{C}$.

There were no differences among the diets in the net appearance of lactic acid in the portal vein and hepatic uptake, whilst the net appearance of pyruvic acid in the portal vein was slightly lower after ingestion of the guar-gum diet than after that of the other two diets.

\section{Insulin, GIP, glucagon and IGF-I}

The lowest mean production of insulin was observed after ingestion of the guar-gum diet (diet B; Table 3). This production represented only $70 \%$ of that recorded after ingestion of the fibre-free diet (diet A) and $80 \%$ of that obtained for the cellulose diet (diet C). Moreover, after intake of diets $\mathrm{A}$ and $\mathrm{C}$ the insulin produced during the first hour postprandially represented respectively 29 and $35 \%$ of the hormone secreted in $8 \mathrm{~h}$, whilst after ingestion of the guar-gum diet the insulin production in the first hour only represented $17 \%$ of the total measured hormone. The kinetic profiles of hepatic uptake of insulin reflected those of insulin production. The HEC for the insulin produced were always higher than $50 \%$. The lowest HEC for insulin were noted for the cellulose diet.

The lowest mean production and HB of glucagon were observed after ingestion of diet B (Table 3); this glucagon production represented only $46 \%$ of that measured after ingestion of diet $\mathrm{C}$ and $59 \%$ of that for diet A. No significant difference in kinetic profile of glucagon production and HEC appeared between the three diets.

Ingestion of guar gum strongly reduced GIP secretion (Table 3). The GIP produced after guar-gum ingestion represented $45 \%$ of that obtained after diet $\mathrm{A}$ and $56 \%$ of that 
Table 3. Production $(P)$ and hepatic balance $(H B)$ of insulin $(m U / 8 h)$, gastric inhibitory polypeptide $(G I P ; n g / 8 h)$ and glucagon $(\mathrm{ng} / 8 \mathrm{~h})$ and mean hepatic extraction coefficients according to the produced hormone (HEP) or according to the quantity of hormone exposed to the liver ( $H E C)$ in the pig after ingestion of the basal non-fibre diet $A$ or diets containing guar gum $(B)$ or cellulose $(C)^{*}$

(Mean values and standard deviations for six determinations)

\begin{tabular}{|c|c|c|c|c|c|c|}
\hline \multirow[t]{2}{*}{ Diet... } & \multicolumn{2}{|l|}{ A } & \multicolumn{2}{|c|}{ B } & \multicolumn{2}{|c|}{$\mathrm{C}$} \\
\hline & Mean & SD & Mean & SD & Mean & SD \\
\hline \multicolumn{7}{|l|}{ Insulin } \\
\hline P & $21096^{\mathrm{a}}$ & 3000 & $14712^{\mathrm{b}}$ & 1504 & $18624^{\mathrm{ab}}$ & 2072 \\
\hline HB & 15264 & $2136^{\mathrm{a}}$ & 11568 & $1360^{b}$ & 9968 & $968^{b}$ \\
\hline HEP & 72 & $10^{\mathrm{a}}$ & 79 & $9^{a}$ & 54 & $5^{\mathrm{b}}$ \\
\hline $\mathrm{HEC}$ & 32 & $4^{a}$ & 34 & $4^{n}$ & 22 & $2^{\mathrm{b}}$ \\
\hline \multicolumn{7}{|l|}{ GIP } \\
\hline $\mathrm{P}$ & $29808^{\mathrm{a}}$ & 5200 & $13400^{\mathrm{b}}$ & 3128 & $23728^{a}$ & 3776 \\
\hline НВ & 8960 & $3512^{\mathrm{ab}}$ & 6352 & $1576^{\mathrm{b}}$ & 9096 & $1952^{\mathrm{a}}$ \\
\hline HEP & 30 & 12 & 47 & 12 & 38 & 8 \\
\hline $\mathrm{HEC}$ & 7 & $3^{\mathrm{a}}$ & 17 & $4^{b}$ & 13 & $3^{a b}$ \\
\hline \multicolumn{7}{|c|}{ Glucagon } \\
\hline $\mathrm{P}$ & $174136^{\mathrm{ab}}$ & 51792 & $103552^{\mathrm{b}}$ & 27952 & $223216^{\mathrm{a}}$ & 53928 \\
\hline $\mathrm{HB}$ & $61504^{\mathrm{a}}$ & 11232 & $37840^{\mathrm{b}}$ & 6688 & $75136^{\mathrm{a}}$ & 9328 \\
\hline HEP & 35 & 6 & 37 & 6 & 34 & 4 \\
\hline $\mathrm{HEC}$ & 10 & 2 & 9 & 2 & 11 & 1 \\
\hline
\end{tabular}

${ }^{\mathrm{a}, \mathrm{b}}$ Mean values in the same row with different superscript letters were significantly different $(P<0 \cdot 05)$.

* For details of composition, see p. 694 and Table 1.

measured after diet $\mathrm{C}$. The kinetic profile of the secretion was not the same for all diets. Thus, GIP production after ingestion of diet A was biphasic with maxima during the first hour and at $6-7 \mathrm{~h}$ after feeding; that noted after diet $\mathrm{B}$ was rather small and uniform during the first $6 \mathrm{~h}$ after the meal, whilst the secretion observed after diet $\mathrm{C}$ was highest during the second, third and fourth hours post-prandially. The HEC for GIP was significantly higher after ingestion of the guar-gum diet (diet B) than after that of the fibre-free diet (diet A).

The gut secretion of IGF-1 was lowest after ingestion of guar gum (Table 4). Whatever the ingested diet, the kinetic profile of IGF-1 gut secretion was quite constant and uniform during the $8 \mathrm{~h}$ of observation. No influence of meal intake was, thus, observed on the level of IGF-1 gut secretion. The liver was responsible for a net uptake of circulating IGF-1. The HEC for gut-produced IGF-1 was significantly higher after ingestion of the guar-gum diet (diet B).

\section{DISCUSSION}

The effects of fibre on post-prandial blood glucose and insulin levels have often been investigated, but little is known about the effects of fibre on the absorption of the other components of a meal and the mechanisms of these effects, or about the effects of fibre on the hepatic metabolism of nutrients and hormones. The latter were the main area of investigation of the present study.

Ingestion of guar gum strongly reduced glucose absorption. Decreased glucose absorption was also observed in man after ingestion of guar gum (Gulliford et al. 1988; Torsdottir et al. 1989). Diminished glucose absorption after the addition of guar gum to the 
Table 4. Insulin-like growth factor $(I G F-1 ; n g / 8 h)$ gut production $(G P)$, hepatic input $(H I)$, hepatic balance $(H B)$ and hepatic extraction coefficients of gut production (HEGP) and of the peptide exposed to the liver $(H E C)$ in the pig after ingestion of the basal non-fibre diet $A$ or diets containing guar gum $(B)$ or cellulose $(C)^{*}$

(Mean values and standard deviations for six determinations)

\begin{tabular}{|c|c|c|c|c|c|c|}
\hline \multirow[t]{2}{*}{ Diet ... } & \multicolumn{2}{|c|}{ A } & \multicolumn{2}{|l|}{ B } & \multicolumn{2}{|c|}{$\mathrm{C}$} \\
\hline & Mean & SD & Mean & SD & Mean & $\mathrm{SD}$ \\
\hline GP & 13216 & $1512^{\mathrm{ac}}$ & 5504 & $1176^{\mathrm{de}}$ & 16848 & $1224^{b 1}$ \\
\hline $\mathrm{HI}$ & 61688 & $6176^{a}$ & 43944 & $3328^{\mathrm{b}}$ & 62104 & $6920^{\mathrm{a}}$ \\
\hline HB & 5192 & 800 & 3968 & 896 & 5048 & 1480 \\
\hline HEGP & 39 & 6 & 72 & $16^{\mathrm{a}}$ & 30 & $9^{c}$ \\
\hline $\mathrm{HEC}$ & 8 & 1 & 9 & 2 & 8 & 2 \\
\hline
\end{tabular}

Mean values in the same row with different superscript letters are significantly different: ${ }^{a^{a} b} P<0.05$; ${ }^{\text {c.d }} P<0.01 ;{ }^{\mathrm{e}, \mathrm{f}} P<0.001$.

* For details of composition, see p. 694 and Table 1.

diet has been attributed to delayed gastric emptying (Holt et al. 1979), but the correlation between gastric emptying and post-prandial absorption has been questioned (Blackburn et al. 1984). Thus, the slower absorption of glucose induced by guar gum does not seem to be explained by delayed gastric emptying, but rather supports the theory of slower digestion or absorption (Hagander et al. 1984). The fundamental importance of viscosity with regard to the physiological effects of guar gum has been reported (Rainbird \& Low, 1986; Torsdottir et al. 1989; Cherbut et al. 1990). The effect of guar gum on glucose absorption can be removed if the property of the fibre to increase the viscosity of a meal is destroyed by hydrolysis or processing of the guar gum (Jenkins et al. 1978; Torsdottir et al. 1989). Moreover, decreased hydrolysis of starch in the small intestine induced by viscous dietary fibre which limits further stages of carbohydrate digestion and absorption appears to be quite important in mechanisms of action for viscous dietary fibre such as guar gum (Isaksson et al. 1982; Hamberg et al. 1989).

The absorbed glucose was primarily extracted by the liver, confirming that there was a direct uptake of glucose by the liver during post-absorptive hyperglycaemia (Barrett et al. 1986; Simões Nunes et al. 1989). The hepatic glucose uptake rate was not modified by the ingestion of guar gum or cellulose.

Cellulose at the level used in the present study, did not influence glucose absorption rate and the kinetic profile of absorption. Cellulose has been shown to reduce glucose absorption to a slight extent in man (Jenkins et al. 1983), as well as having no effect on the digestion and intestinal absorption of lipids in the rat (Borel et al. 1989), whilst guar gum reduced lipid absorption (Turner et al. 1990; A. Girard-Globa, C. Simões Nunes \& K. Malmlöf, unpublished results).

Additionally the insulin (Malmlöf et al. 1989) and GIP responses were reduced after the guar-gum-supplemented diet, while cellulose failed to change their productions. Decreased insulin and GIP secretions have also been observed in man after guar-gum ingestion (Morgan et al. 1979; Gulliford et al. 1988). Carbohydrate in the upper gastrointestinal tract stimulates GIP release; thus, a reduced GIP response to a given meal indicated a reduced concentration of glucose for absorption in the upper part of the gut. Reduced insulin release after guar-gum ingestion appeared to be due mainly to lower glucose absorption and lower secretion of GIP. Guar-gum ingestion was also found to reduce insulinotropic 
amino acid absorption (Simões Nunes \& Malmlöf, 1991) and this could have contributed to a lower insulin release. However, the observed reduced insulin release was not found to be associated with a change in hepatic insulin extraction. Guar-gum ingestion appeared to reduce glucagon secretion. Such an effect was not observed in man by Gulliford et al. (1988). The present work also confirmed that the HEC for insulin was higher than that for glucagon (Ishida et al. 1983; Simões Nunes et al. 1991).

The net uptake of circulating IGF-1 suggests that most of the plasma IGF-1 is of nonhepatic origin and may have autocrine-paracrine or endocrine actions (Daughaday \& Rotwein, 1989). From our findings it appears that IGF-1 is largely produced by the gastrointestinal tissues and that the production is independent of the meal intake. The first observation suggests that IGF-1 may have an important role in gut tissue growth and enterocyte renewal. However, guar gum has been shown to have a stimulatory effect on intestinal cell proliferation in rats (Johnson \& Gee, 1986). It appears that further studies should be carried out on the role of IGF-1 in the very complex mechanisms of intestinal cell proliferation. The lower IGF-1 plasma concentrations and splanchnic production after adaptation to a guar-gum diet were in agreement with findings on IGF-1 secretion and nutritional status observed in man, calf, rat and pig (Prewett et al. 1982; Isley et al. 1983; Coxam et al. 1989; Buonomo \& Baile, 1991).

In conclusion, our results demonstrated that guar gum strongly inhibited the in vivo apparent absorption of glucose and the appearance of pyruvic acid in the portal vein, and reduced the production of insulin, glucagon and GIP, only changing the HEC in the case of GIP. The latter suggests that the intestinal mechanisms of action of guar gum are sufficient to regulate the observed metabolic effects. Furthermore, we showed that the gut was a net producer of IGF-1 and that the liver had a net uptake of this peptide.

The authors thank S. Guérin, G. Brachet, P. Vaugelade and P. Vaissade for skilful technical assistance.

\section{REFERENCES}

Barrett, E. I., Gusberg, R., Ferrannini, E., Tepler, I., Felig, P., Jacob, P., Smith, D. \& De Fronzo, R. A. (1986). Amino acid and glucose metabolism in the postabsorptive state and following amino acid ingestion in the dog. Metabolism 35, 709-717.

Blackburn, N. A., Redfern, J. S., Jaris, H., Holgate, A. M., Hanning, I., Scarpello, J. H. B., Johnson, I. T. \& Read, N. W. (1984). The mechanism of action of guar gum is improving glucose tolerance in man. Clinical Science 66, 329-336.

Borel, P., Lairon, D., Senft, M., Garzino, P. \& Lafont, H. (1989). Lack of effect of purified cellulose and hemicellulose on the digestion and the intestinal absorption of dietary lipids in the rat. Annals of Nutrition and Metabolism 33, 237-245.

Buonomo, F. C. \& Baile, C. A. (1991). Influence of nutritional deprivation on insulin-like factor I, somatotropin, and metabolic hormones in swine. Journal of Animal Science 69, 755-760.

Cherbut, C., Albina, E., Champ, M., Doublier, J. L. \& Lecannu, G. (1990). Action of guar gums on the viscosity of digestive contents and on the gastrointestinal motor function in pigs. Digestion 46, 205-213.

Coxam, V., Bauchart, D., Durand, D., Davicco, M. J., Opneer, F. \& Barlet, J. P. (1989). Nutrient effects on the hepatic production of somatomedin-C (IGF-1) in the milk-fed calf. British Journal of Nutrition 62, 425-437.

Daughaday, W. H. \& Rotwein, P. (1989). Insulin-like growth factors I and II. Peptide, messenger ribonucleic acid and gene structures, serum, and tissue concentrations. Endocrine Reviews 10, 69-91.

Gulliford, M. C., Bicknell, E. J. \& Scarpello, J. H. B. (1988). Effect of guar on amino acid absorption and the blood glucose, insulin, C-peptide and glucagon responses to jejunal amino acid and glucose perfusion in man. European Journal of Clinical Nutrition 42, 871-876.

Hagander, B., Scherstén, B., Asp, N. G., Sartor, G., Agardh, C. D., Schrezenmeir, J., Kasper, H., Ahrén, B. \& Lundquist, I. (1984). Effect of dietary fibre on blood glucose, plasma immunoreactive insulin, C-peptide and GIP responses in non-insulin-dependent (type 2) diabetics and controls. Acta Medica Scandinavica 215. $205-213$.

Hamberg, O., Rumessen, J. J. \& Gudman-Hoyer, E. (1989). Inhibition of starch absorption by dietary fiber. Scandinavian Journal of Gastroenterology 24, 103-109.

Heaton, K. W. (1983). Dietary fibre in perspective. Human Nutrition Clinical Nutrition 37C, 151--170. 
Hill, J. B. \& Kessler, G. (1961). An automated determination of glucose utilising a glucose oxidase-peroxidase system. Journal of Clinical Medicine 57, 970-980.

Holt, S., Heading, R. C., Carter, D. C., Prescott, L. F. \& Tothill, P. (1979). Effect of gel fibre on gastric emptying and absorption of glucose and paracetamol. Lancet $\mathbf{i}, 636-639$.

Isaksson, G., Lundquist, I. \& Ishe, I. (1982). Effect of dietary fibre on pancreatic enzyme activity in vitro. The importance of viscosity, $\mathrm{pH}$, ionic strength, adsorption and time of incubation. Gastroenterology 82, 918-924.

Ishida, T., Chou, J., Lewis, R. M., Hartley, C. J., Entman, M.\& Field, J. B. (1983). The effect of ingestion of meat on hepatic extraction of insulin and glucagon and glucose output in conscious dogs. Metabolism: Clinical and Experimental 32, 558-567.

Isley, W. L., Underwood, L. E. \& Clemmons, D. R. (1983). Dietary components that regulate somatomedin-C concentrations in humans. Journal of Clinical Investigation 71, 175-182.

Jenkins, D. J. A., Wolever, T. M. S., Jenkins, A. L., Thorne, M. J., Lee, R., Kalmusky, J., Reichert, R. \& Wrong, G. S. (1983). The glycaemic index of foods tested in diabetic patients: a new basis for carbohydrate exchange favouring the use of legumes. Diabetologia 24, 257-264.

Jenkins, D. J. A., Wolever, T. M. S., Leeds, A. R., Gassull, M. A., Haisman, P., Dilawari, J., Goff, D. V., Metz, G. L. \& Alberti, K. G. M. M. (1978). Dietary fibres, fibre analogues and glucose tolerance: importance of viscosity. British Medical Journal i, 1392-1394

Johnson, I. T. (1990). Fibre sources for the food industry. Proceedings of the Nutrition Society 49, 31-38.

Johnson, I. T. \& Gee, J. M. (1986). Gastrointestinal adaptation in response to soluble non-available polysaccharides in the rat. British Journal of Nutrition $\mathbf{5 5}, 497-505$.

Laplace, I. P. \& Lebas, F. (1981). Plantix (fiber) deficiency in animal physiopathology. World Review of Nutrition and Dietetics 37, 84-176.

Malmlöf, K., Simões Nunes, C. \& Askbrant, S. (1989). Effects of guar gum on plasma urea, insulin and glucose in the growing pig. British Journal of Nutrition 61, 67-73.

Malmlöf, K., Simões Nunes, C. \& Örberg, J. (1988). Effects of a high dietary fibre level on postprandial portoarterial differences in the plasma concentrations of immunoreactive insulin, glucose and free amino acids in the growing pig. Swedish Journal of Agricultural Research 18, 67-75.

Minaire, Y., Forichon, J. \& Studievic, C. (1967). Dosage fluorimétrique enzymatique par l'autoanalyzer (Fluorimetric enzymic determinations with an autoanalyser). In Automation in Analytical Chemistry, Technicon Symposium, vol. 2. pp. 145-150. New York: Mediad Inc.

Minaire, Y., Foucherand, F. \& Studievic, C. (1965). Adaptation du dosage de l'acide lactique par voie enzymatique à l'autoanalyzer (Adaptation of lactic acid enzymic determination to the autoanalyser). In $I V$ Symposium Internationale Technicon, Paris. Domont: Technicon.

Morgan, L. M., Goulder, T. J., Tsiolakis, D., Marks, V. \& Alberti, K. G. M. M. (1979). The effect of unabsorbable carbohydrate on gut hormones: modification of postprandial GIP secretion by guar. Diabetologia 17, 85-89.

Prewett, T. E., D'Ercole, A. J., Switzer, B. R. \& Van Wyk, J. J. (1982). The relationship of serum immunoreactive Somatomedin-C to dietary protein and energy in the growing rat. Journal of Nutrition 112, 144-150.

Rainbird, A. L. \& Low, A. G. (1986). Effect of guar gum on gastric emptying in growing pigs. British Journal of Nutrition 55, 87-98.

Rémésy, C. \& Demigné C. (1989). Specific effects of fermentable carbohydrates on blood urea flux and ammonia absorption in the rat cecum. Journal of Nutrition 119, 560-565.

Rérat, A., Chayvialle, J. A., Kandé, J., Vaissade, P., Vaugelade, P.\& Bourrier, T. (1985), Metabolic and hormonal effects of test meals with various protein contents in pigs. Canadian Journal of Physiology and Pharmacology 63, 1547-1559.

Simões Nunes C., Galibois I., Rérat A., Savoie L. \& Vaugelade P. (1991). Hepatic and portal-drained viscera balances of amino acids, insulin, glucagon and gastrin in the pig after ingestion of casein or rapeseed proteins. Reproduction, Nutrition, Développement 31, 217-231.

Simões Nunes C. \& Malmlöf, K. (1992). Interorgan movements of amino acids in the pig: effects of dietary fibre. Amino Acids 2, 77-86.

Simões Nunes, C., Rérat, A., Galibois, I., Vaugelade, P. \& Vaissade, P. (1989). Hepatic and gut balances of glucose, amino-nitrogen, ammonia and urea in the pig after ingestion of casein or rapeseed proteins. Nutrition Reports International 40, 901-907.

Snedecor, G. W. \& Cochran, W. G. (1967). Statistical Methods. Ames, Iowa: Iowa State University Press

Torsdottir, I., Alpstein, M., Andersson, H. \& Einarsson, S. (1989). Dietary guar gum effects on postprandial blood glucose, insulin and hydroxyproline in humans. Journal of Nutrition 119, 1925-1931.

Turner, P. R., Tuomileheto, J., Happoner, P., La Ville, A. E., Shaikh, M. \& Lewis, B. (1990). Metabolic studies on the hypolipidaemic effect of guar gum. Atherosclerosis 81, 145-150. 